\title{
Multi Metal lon Recognizing Unsymmetrical tetra dentate Schiff bases Associated with Antifungal activity
}

\author{
SELVARAJ SHUNMUGAPERUMAL', SARANYA DHASARATHAN", \\ KAMATCHI SELVARAJ. ${ }^{1 *}$ and ILANGO KALIAPPAN ${ }^{2}$
}

\begin{abstract}
'Department of Chemistry, Government Arts College for Men (Autonomous),Nandanam, Chennai-600 035, Tamil Nadu, India.

${ }^{2}$ Department of Pharmaceutical Chemistry, SRM College of Pharmacy, SRM Institute of Science and Technology, Kattankulathur-603 203, Chengalpattu District, Tamil Nadu, India.

${ }^{*}$ Corresponding author E-mail: porbal96@gmail.com
\end{abstract}

http://dx.doi.org/10.13005/ojc/370410

(Received: July 07, 2021; Accepted: August 08, 2021)

\section{ABSTRACT}

\begin{abstract}
New unsymmetrical Schiff bases containing azomethine moiety with simple aromatic section in one side and ferrocene fragment attached imine on the other side have been synthesized. Advent of metal-to-ligand charge transfer band for the coordination of $\mathrm{Cu}^{2+}$ ions with receptors and appropriate changes in UV-Visible spectra for other metal ion combination with the sensor is reported. Observed extravagant $\Delta \mathrm{E}_{\mathrm{p}}$ values suggest quasi-reversible process. The $\Delta \mathrm{l}_{\mathrm{pa}}$ amount calculated from the anodic current $I_{p a}^{p}$ value noticed for receptor solution and different metal ion added sensor solution discloses the concentration of metal ions required for effective sensing. The synthesized ligands were subjected to antimicrobial activity against four bacterial and two fungal stains and the zone of inhibition (in $\mathrm{mm}$ ) was calculated. Further molecular docking study was carried out and the binding energy $\left(\mathrm{Kcal}^{\mathrm{mol}}{ }^{-1}\right)$ for the synthesized ligand $\left(R_{1}\right.$ and $\left.R_{2}\right)$ with the selected protein was intended.
\end{abstract}

Keywords: Azomethine, Cation sensors, Binding attitude, Molecular docking, MLCT Band, Unsymmetrical Schiff base.

\section{INTRODUCTION}

Researchers are interested to develop selective chemosensors to identify the trace amount of transition metal ions involved in many biological processes. Not only have that, the influence of metal ions having redox behavior in the environment also captivated the attraction of scientist to synthesize sensor compounds capable of identifying different metal ions ${ }^{1}$. Qualities like non-destructive nature, easiness in synthesis, selectiveness towards target entities, quick retention time and capability to diagnose biological samples ${ }^{2}$ project chemosensors to unique place rather than the other instrumental method of analysis ${ }^{3}$.

Preparation of sensors proficient in identifying cations in solution and converting the action of recognition in to documentable signal are of flourishing field with enormous amount of published

This is an Open Access article licensed under a Creative Commons license: Attribution 4.0 International (CC- BY). Published by Oriental Scientific Publishing Company @ 2018 
works ${ }^{4}$. Interlocking ability of the synthesized compounds with hazardous heavy metal cations and anions hinge on the $\pi$ electrons cloud available on $\mathrm{C}=\mathrm{N}$ group which in turn is influenced by heterocyclic aromatic part with nitrogen and inductive effect of substituent groups ${ }^{5}$. Metal-to-Ligand charge-transfer and intramolecular charge transfer may emerge for the union of sensor and targeted ions ${ }^{6}$.

Copper ions control the biological activity of cytochrome c oxidase, superoxide dismutase and tyrosinase enzymes. Despite, higher insertion modify the functions of enzymes and lead to antagonistic actions like, lethargy, hike in blood pressure, nausea and Alzheimer's diseases ${ }^{7}$. Solubility of $\mathrm{Hg}^{2+}$ in water makes it to penetrate through membrane of the cell leading to malfunction of brain, letdown of kidney functions, infirmity of neuro system and Minamata disease ${ }^{8}$. Consumption of chocolate, milk and cookies made of milk, canned food and hydrogenated oils induces $\mathrm{Ni}^{2+}$ ion in biological systems. Development of cancer in respiratory organs, pneumonia, asthma and malfunctioning of nervous system has been reported ${ }^{9}$ for the excess intake of $\mathrm{Ni}^{2+}$ ions.

Consumption of $\mathrm{Cd}^{2+}$ ions toxicity prompts productivity, hepatic and cardiovascular dysfunctions ${ }^{10}$. Harmfulness of $\mathrm{Pb}^{2+}$ ion exposure include procreative malady in human, neurological dysfunctions and loss of strength at bone joints ${ }^{11}$. Health hazards persuaded by manganese toxicity include damage to immune system, central nervous system, kidney function and exocrine \& endocrine function of pancreas ${ }^{12}$.

Here in we report the synthesis of new unsymmetrical Schiff bases $N^{\prime}-((E)-$ 2-nitrobenzylidene)-2-((E)-2-(ferrocenylidene) hydrazine-1-carbothiohydrazide and $N^{\prime}-((E)-2-$ hydroxy-5-nitrobenzyliden-2-((E)-2-(ferrocenylidene) hydrazine-1-carbothiohydrazide containing aromatic part at one end and ferrocene compound at the other end of the main frame structure. Spectroscopic and redox studies exposes that synthesized receptor possess sensing aptitude towards metal ions like, $\mathrm{Hg}^{2+}, \mathrm{Mn}^{2+}, \mathrm{Pb}^{2+}, \mathrm{Cd}^{2+}, \mathrm{Ni}^{2+}$ and $\mathrm{Cu}^{2+}$.
Reported literature ${ }^{13}$ discloses that the biological and chemical activities of Schiff bases depend upon the $\mathrm{sp}^{2}$ hybridized nitrogen donor atom of the azomethine group. The proteins present in microorganisms find suitability to form hydrogen bond with the active site of azomethine group containing high electro negative nitrogen atom, which in turn is responsible for the anticancer, antibacterial and antifungal activities ${ }^{14}$. Prokaryotic nature of bacteria (unicellular organism without nucleus, cell wall \& organelles and survives on the host entities) helps to develop enormous amount of antibacterial commixture whereas eukaryotic nature of fungi (multicellular organism with nucleus, cell wall \& organelles and endures independently) prevent the formulation of antifungal agents ${ }^{15}$. The newly synthesized sensor by us exhibit better antifungal activity rather than antibacterial activities.

\section{EXPERIMENTAL}

\section{Materials}

Chemicals [AR grade] such as carbon disulfide, 2-hydroxy-5-nitrobenzaldehyde, ferrocene carboxaldehyde, hydrazinehydrate, 2-nitrobenzaldehyde and silica gel were purchased from E.Merck industry. They were used without further purification. Analytical grade $\mathrm{NiCl}_{2}, \mathrm{MnCl}_{2}$, $\mathrm{CuCl}_{2}, \mathrm{HgCl}_{2}, \mathrm{~Pb}(\mathrm{OAc})_{2}$ and $\mathrm{Cd}(\mathrm{OAc})_{2}$ used in the electronic spectral and $\mathrm{CV}$ studies were procured from Sigma-Aldrich. Acetonitrile [HPLC grade] obtained from E-Merck and absolute ethanol [spectral grade] acquired from Commercial Alcohols, Canada was used for spectral studies. Tetrabutylammoniumperchlorate [99+\%] secured from Chemical Center, Mumbai was used as such without purification.

\section{Instruments}

Bruker Daltonics esquire 3000 spectrometer was used to record mass spectra. BRUKER AVANCE spectrometer $\left[500 \mathrm{MHz}\right.$ ] engaging $\mathrm{C}_{2} \mathrm{D}_{5} \mathrm{OD}$ solvent was adopted to document proton NMR spectra. PerkinElmer 337 spectrometer was engaged to register FTIR spectra in the range of $400-4000 \mathrm{~cm}^{-1}$ using $\mathrm{KBr}$ pellets. SHIMADZU MODELUV-1800 240V spectrophotometer was affianced to observe UV-Visible spectral studies between 200 and $800 \mathrm{~nm}$. CHI electrochemical 
analyzer 1200B model was employed to draw cyclic voltammograms using platinum as counter electrode, $\mathrm{Ag} / \mathrm{AgCl}$ as reference electrode and glassy carbon as working electrode. The $\mathrm{C}, \mathrm{H}$ and $\mathrm{N}$ contents were analyzed with Herarus $\mathrm{C}-\mathrm{H}-\mathrm{N}$ rapid analyzer.

Synthesis of $\mathrm{N}^{\prime}-((E)-2-$ Nitrobenzylidene)-2-((E)-2(ferrocenylidene)hydrazine-1- carbothiohydrazide [R1]

Hydrazinehydrate and carbon disulphide in 3:1 molar ratio was refluxed for ten hours at $80^{\circ} \mathrm{C}$ along with 0.15 mole of 2-chloroethanol as catalyst to prepare the precursor compound thiocarbohydrazide ${ }^{16}$. To a clear solution $[0.01$ mole/25 $\mathrm{mL}$ ] of purified thiocarbohydrazide in ethanol, a mixture of 2-nitrobenzaldehyde $(0.01 \mathrm{~mol})$ and ferrocene carboxaldehyde $(0.01 \mathrm{~mol})$ in $180 \mathrm{~mL}$ ethanol was added. After half an hour stirring, the reaction mixture was refluxed for 6-7 hours. Thin layer chromatographic technique was used to check the progress of the reaction at various time intervals. Filtration was carried out after cooling and the filtrate was concentrated to get reddish yellow colored $N^{\prime}$ ((E)-2-Nitrobenzylidene)-2-((E)-2-(ferrocenylidene) hydrazine-1-carbothiohydrazide. Column having silica gel as stationary phase was used for the purification of crude sample. Ethanol was used as eluent. Color: Dark reddish orange. Yield: $0.538 \mathrm{~g}(91 \%)$, m.p. $69^{\circ} \mathrm{C}$.

Synthesis of $N^{\prime}-((E)-2$-hydroxy-5-nitrobenzylidene-2-((E)-2-(ferrocenylidene)hydrazine-1carbothiohydrazide [R2]

Solution containing 0.01 mole of thiocarbohydrazide in $25 \mathrm{~mL}$ of ethanol was added with stirring to another solution having 0.01 mole of 2-hydroxy-5-nitrobenzaldehyde and 0.01 mole of ferrocene carboxaldehyde in $180 \mathrm{~mL}$ ethanol. The reaction mixture was stirred for another half an hour and then refluxed for 6-7 hours. The progress of the reaction at various time intervals was checked using thin layer chromatographic technique. The reaction mixture was filtered after cooling. Greenish yellow color solid was obtained after concentrating the filtrate. The product was further purified by column chromatography using silica gel as stationary phase and ethanol as eluent. Yield: $0.5442 \mathrm{~g},(91 \%)$, Color: reddish yellow, m.p. $70^{\circ} \mathrm{C}$.
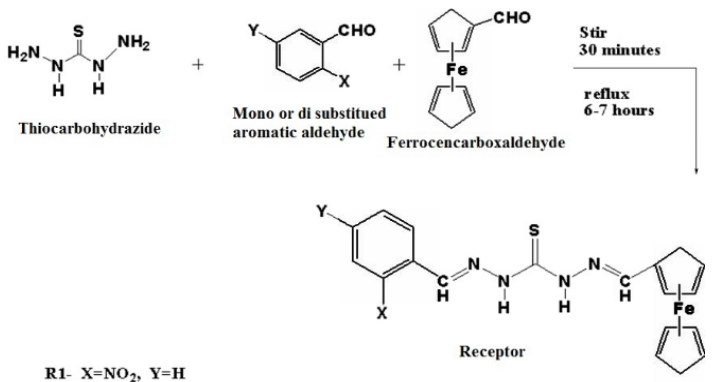

R1- $\mathrm{X}=\mathrm{NO}_{2}, \mathrm{Y}=\mathrm{H}$ R2- $\mathrm{X}=\mathrm{OH}, \quad \mathrm{Y}=\mathrm{NO}_{2}$

Scheme of Synthesis

R1-N'-((E)-2-Nitrobenzylidene)-2-((E)-2-(ferrocenylidene) hydrazine-1- carbothiohydrazide

R2- $N$ '-((E)-2-hydroxy-5-nitrobenzylidene-2-((E)-2(ferrocenylidene)hydrazine-1-carbothiohydrazide

In-vitro activities for microorganisms

Antimicrobial studies were carried out in triplicate (in-vitro) for the synthesized ligands by standard method ${ }^{17}$ against four bacteria at $37^{\circ} \mathrm{C}$ and two fungi at room temperature.

\section{Molecular docking studies}

The molecular docking study was carried out using Auto dock version 4.2.6 $6^{18}$ to investigate the binding mode of the synthesized compounds $\mathrm{R} 1$ and R2 with the target protein. The 3D crystal structure with Protein Data Bank PDB code 1PTF (Streptococcus faecalis), 6KVQ (Staphylococcus aureus), 7BU2 (Escherichia coll), 4YXB (Salmonella typhimurium) 3K4Q (Aspergillus niger), 6TZ6 Candida albicans) was used as target protein and it was extracted from Research Collaboratory for Structural Bioinformatics (www.RCSB.org). Molecular Graphics Laboratory (MGL) tools of Auto dock were employed to get the docking score. Engaging 3D optimization tool, the structures of the compounds R1 and R2 were drawn using ChemSketch and converted to 3D structure. Geometrical optimization of ligands using ligand module was implemented using Molecular Mechanics Force Field 94 (MMFF94) as implemented in the software. The analysis was done by docking the prepared ligand with the selected protein for its affinity towards the particular amino acid residue present and calculated the $\mathrm{H}$-bond interaction and binding energy ( $\mathrm{K} \mathrm{Cal} / \mathrm{mole})$.

\section{Elemental and Mass Spectral analysis}

The data obtained on elemental analysis of the synthesized compounds matches very well with 
the theoretical values. R1 (Found: $\mathrm{C}, 50.61 ; \mathrm{H}, 3.73 ; \mathrm{N}$, 15.51; Fe, 12.18; Calc. for $\mathrm{C}_{19} \mathrm{H}_{17} \mathrm{~N}_{5} \mathrm{O}_{2} \mathrm{SFe}$ : C, 50. 66; H, 3.77; N, 15.55; Fe, $12.20 \%$ ). R2 (Found: C, 50.59; $\mathrm{H}, 3.70 ; \mathrm{N}, 15.47 ; \mathrm{Fe}, 12.16$; Calc. for $\mathrm{C}_{19} \mathrm{H}_{17} \mathrm{~N}_{5} \mathrm{O}$ SFe: C, 50.66; H, 3.77; N, 15.55; Fe, $12.20 \%$ ).

On mass spectral analysis, the advent of molecular peak $(\mathrm{ESI}) \mathrm{m} / \mathrm{z}$ at 434 and 450 respectively for the compounds $N^{\prime}-((E)-2-N i t r o b e n z y l i d e n e)-2-((E)$ 2-(ferrocenylidene) hydrazine-1-carbothiohydrazide \& $N^{\prime}-((E)$-2-hydroxy-5-nitrobenzylidene-2- $((E)-2-$ (ferrocenylidenehydrazine-1-carbothiohydrazide confirm the formation of expected receptors.

\section{FTIR Spectral analysis}

In the FTIR spectrum of compound R1 (Fig. 1), the peak observed around $500 \mathrm{~cm}^{-1}$ and $830 \mathrm{~cm}^{-1}$ are assigned to ferrocene cyclopentadienyl ring tilt stretching vibration and $\mathrm{C}-\mathrm{H}$ out of plane bend vibrations respectively ${ }^{19}$. The peak positioned between $900 \mathrm{~cm}^{-1}$ to $1080 \mathrm{~cm}^{-1}$ are allocated to the $\delta-\mathrm{C}-\mathrm{C}-\mathrm{H}$ bending vibration in the penta cyclic ring. The peak at $1104 \mathrm{~cm}^{-1}$ is allotted for breathing ring deformation ${ }^{20}$ vibration. The peaks appeared at $1340 \mathrm{~cm}^{-1}, 1519 \mathrm{~cm}^{-1}$ and $1567 \mathrm{~cm}^{-1}$ are assigned for $\mathrm{C}=\mathrm{S}$ group stretching vibration, $\mathrm{C}-\mathrm{C}$ stretching vibration of pentacyclic ring and $\mathrm{NO}_{2}$ group vibration respectively. The appearance of $-\mathrm{C}=\mathrm{N}$ stretching vibration peak at $1650 \mathrm{~cm}^{-1}$ confirms the formation of Schiff base and is lower than the vibration frequency of $-\mathrm{C}=\mathrm{O}$ group of the $-\mathrm{CHO}$ group present in ferrocene $\left(1678 \mathrm{~cm}^{-1}\right)^{19}$. The absorption peak emerged at $2059 \mathrm{~cm}^{-1}$ has been earmarked for aromatic stretching vibration. The peaks observed between $3200-3400 \mathrm{~cm}^{-1}$ is attributed to stretching vibration of secondary amine and water of hydration. Compound $\mathrm{R} 2$ also give the above mentioned peaks and the stretching vibrational modes of phenolic $-\mathrm{OH}$ appears along with secondary amine and water of hydration peaks in $3200-3400 \mathrm{~cm}^{-1}$ region itself ${ }^{21}$.

\section{NMR Spectral analysis}

The proton NMR spectrum of $\mathrm{R} 1$ in $\mathrm{C}_{2} \mathrm{D}_{5} \mathrm{OD}$ solvent (Fig. 2) contains relevant peaks and are assigned accordingly $\delta$,(ppm) $8.4(\mathrm{~s}, 2 \mathrm{H}, \mathrm{NCH}), 7.8$ (m, 4H aromatic), 4.8(m, 2H, (cp(subt.)), 4.4(m, $2 \mathrm{H}$, (cp(subst.)), 4.2(s, 5H,( cp(unsubst.)), 1.19 (s, $2 \mathrm{H}, 2 \mathrm{NH})$. For compound $\mathrm{R} 2$ alike spectral peaks 8.4(m, 2H, NCH), $8.3(\mathrm{~s}, 1 \mathrm{H}$, aromatic), $8.1(\mathrm{~s}, 1 \mathrm{H}$, aromatic), 7.0 (s, $1 \mathrm{H}, \mathrm{Ar}), 4.4(\mathrm{~m}, 4 \mathrm{H}$, (cp( subst.)), 4.2 ( $\mathrm{m}, 2 \mathrm{H}$, (cp(unsubst.)), 3.9(s, 5H, cp unsubst), $1.14(\mathrm{~s}, 2 \mathrm{H}, \mathrm{NH})$, along with a prominent singlet at $\delta$ 5.0(s, phenolic-OH) appear in the spectrum.

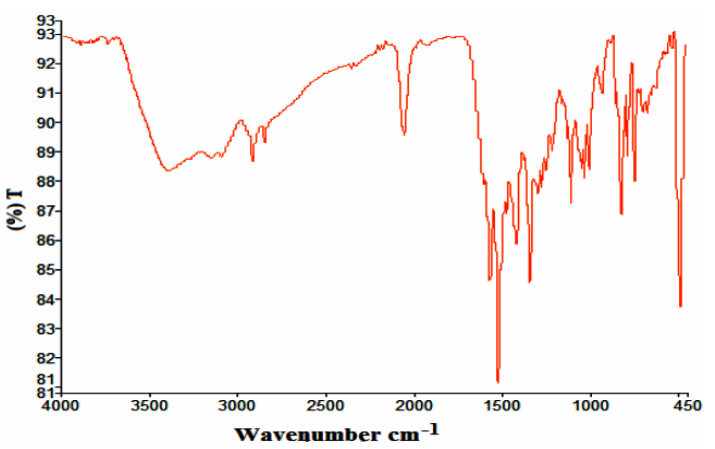

Fig. 1. FTIR spectrum of R1
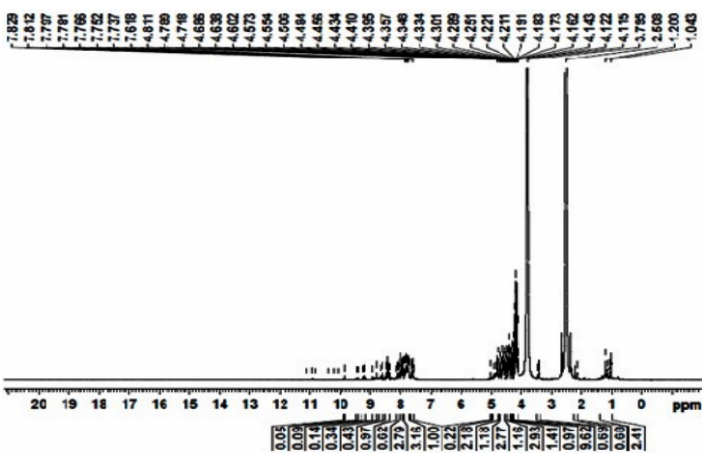

Fig. 2. Proton NMR spectrum of R1

RESULTS AND DISCUSSION

\section{Investigation of sensing nature of receptors}

Exploration of the ability of receptors to imprisonment with the various metal ions was carried out by titration method while recording the UVVisible spectra. Twenty $\mu \mathrm{L}$ aliquots of metal solutions $\left(10^{-2} \mathrm{M}\right)$ were added to $2.5 \mathrm{~mL}$ of receptor solution $\left(10^{-5} \mathrm{M}\right)$ taken in the quartz cell. Since, chloride salts of copper, mercury and nickel are soluble in acetonitrile, solution of the receptor in acetonitrile was used for the above three metal salt solutions. Alcoholic solution of receptors was used for the chloride salts of manganese and acetate salts of lead \& cadmium as these salts are soluble in ethanol. In acetonitrile $\mathrm{R} 1$ shows two shoulders around $259 \mathrm{~nm}$ and $313 \mathrm{~nm}$ (Fig. 3a). Alcoholic solution of R1 displays three peaks near $205 \mathrm{~nm}, 243 \mathrm{~nm}$ and $313 \mathrm{~nm}$ (Fig. 3b). Aromatic ring $\pi-\pi^{\star}$ transitions are assigned for above observation ${ }^{22}$. 

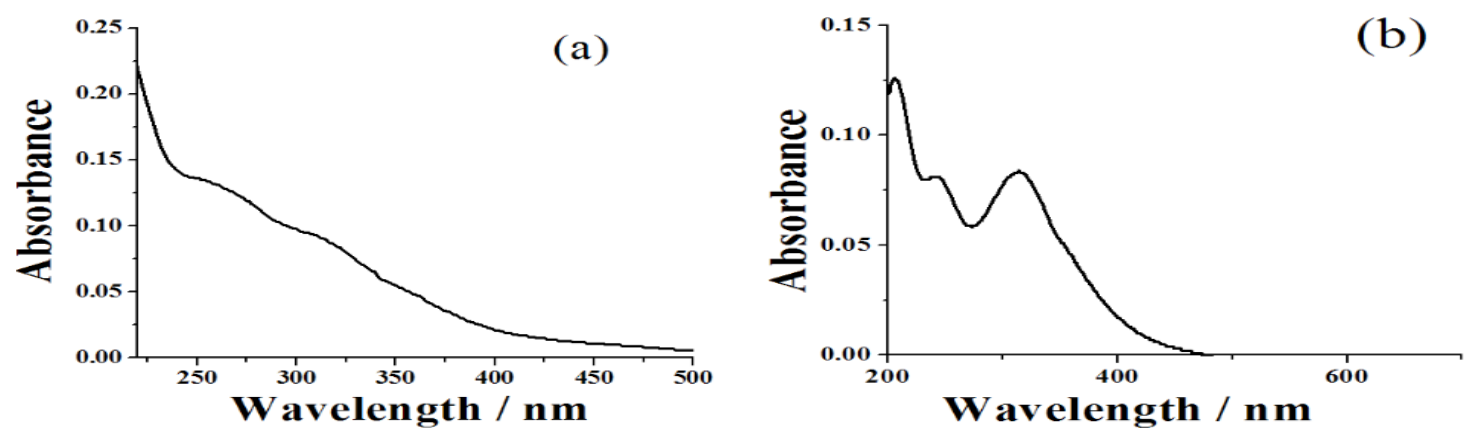

Fig. 3. Electronic spectra of R1 in a) acetonitrile b) ethanol

Effective coordination of $\mathrm{Cu}^{2+}$ ions with receptor is exposed by the development of new prominent peaks around $305 \mathrm{~nm}, 350 \mathrm{~nm}$ and $460 \mathrm{~nm}$ (Fig. 4a). The $460 \mathrm{~nm}$ peak (Fig. 4b) has been assigned ${ }^{23}$ for MLCT band which has
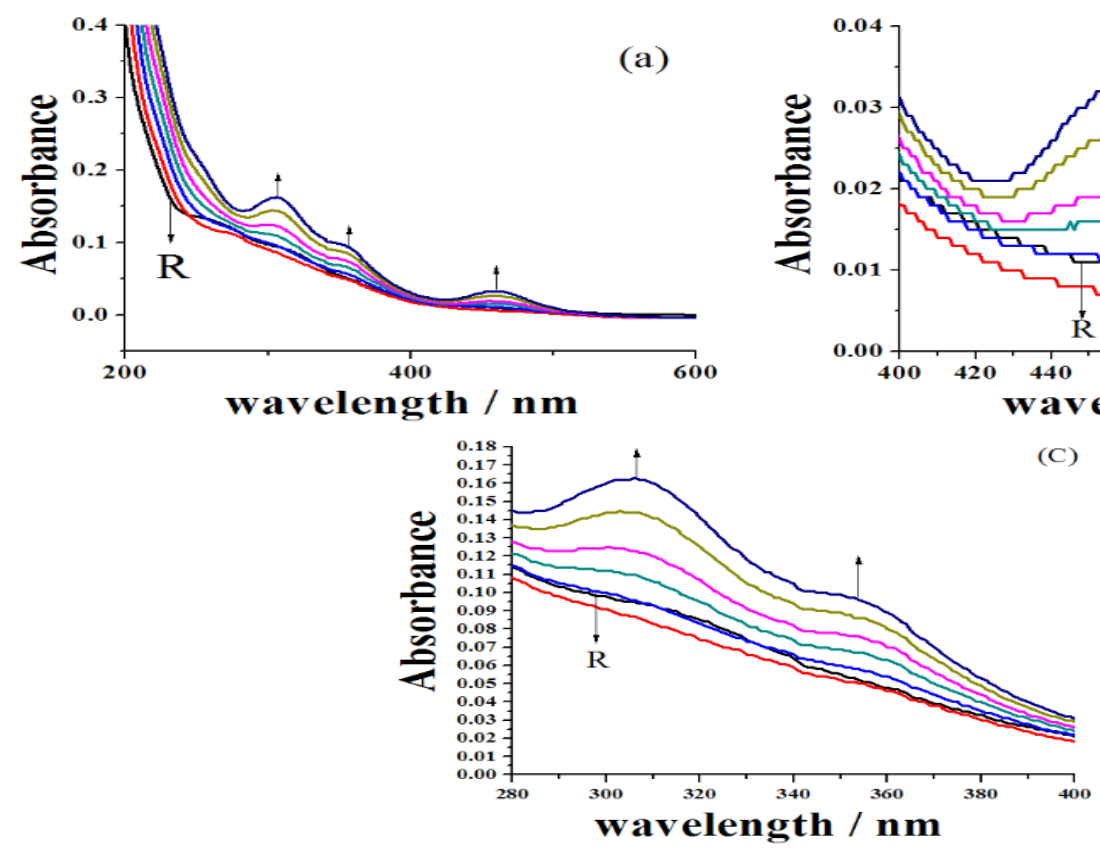

Fig. 4. Spectral changes noticed for the addition of $\mathrm{Cu}^{2+}$ ion to $\mathrm{R} 1$ a) Overall changes b) Formation of MLCT band $\mathrm{c}$ ) Development additional peaks near $305 \mathrm{~nm}$ and $350 \mathrm{~nm}$

Successive addition of $\mathrm{Hg}^{2+}$ ions generate new peak around $237 \mathrm{~nm}$ (Fig. 5a) and $\mathrm{Pb}^{2+}$ ions cause overall blue shift for all the base peaks (Fig. 5b) of the receptor R1. Similarly consecutive addition of $\mathrm{Ni}^{2+}$ ions gives a shoulder around $269 \mathrm{~nm}$ (Fig. 5c). Increase in absorbance value is noticed in the overall wavelength region for cumulative addition of $\mathrm{Mn}^{2+}$ and for $\mathrm{Cd}^{2+}$ ions along with the disappearance of shoulder at $243 \mathrm{~nm}^{22}$.

Aromatic ring $\pi-\pi^{\star}$ transition of R2 appear as a shoulder around $298 \mathrm{~nm}$ in acetonitrile and as developed after the coordination of $\mathrm{Cu}^{2+}$ ions with receptor. Development of additional peaks near $305 \mathrm{~nm}$ and $350 \mathrm{~nm}$ (Fig. 4c) at the expenses of the shoulder peaks of receptor also ascertain the sensing capacity of R1.

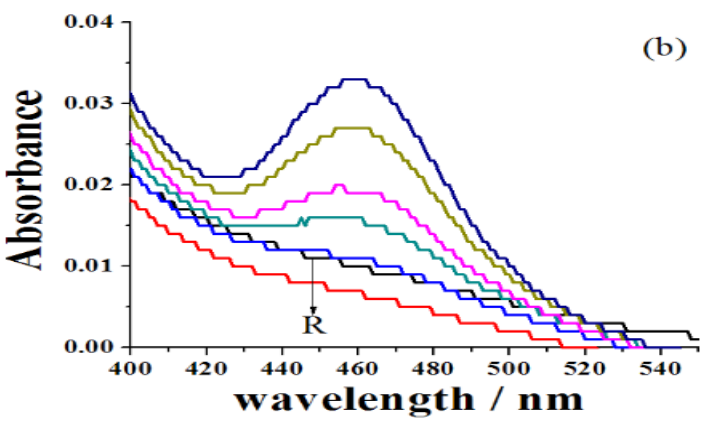

(C) a prominent peak at $313 \mathrm{~nm}$ in ethanol (Figure. 6).

Spectral changes observed for the addition of $\mathrm{Cu}^{2+i o n s}$ to $\mathrm{R} 2$ also generate peaks near $303 \mathrm{~nm}$, $354 \mathrm{~nm}$ and $460 \mathrm{~nm}$ (Fig. 7a,b,c), which confirms that $\mathrm{R} 2$ is efficiently sensing the $\mathrm{Cu}^{2+}$ ions.

Discerning ability of $\mathrm{R} 2$ towards $\mathrm{Hg}^{2+}, \mathrm{Ni}^{2+}$ and $\mathrm{Pb}^{2+}$ ions is exposed by the formation of new peak at $230 \mathrm{~nm}$ for $\mathrm{Hg}^{2+}$ (Fig. 8a), blue shift of $298 \mathrm{~nm}$ shoulder to $278 \mathrm{~nm}$ for $\mathrm{Ni}^{2+}$ (Fig. 8b) and conversion of $313 \mathrm{~nm}$ peak to a broad shoulder at the same wavelength (Figure 8c). 

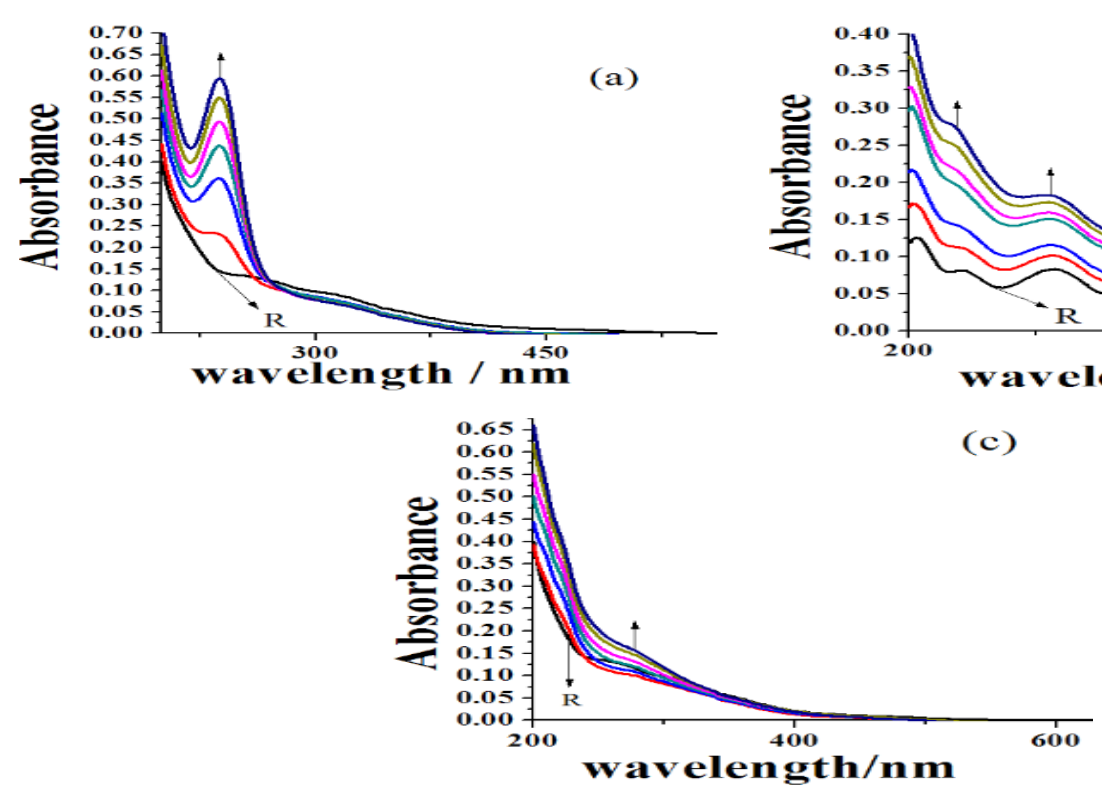

Fig. 5. Spectral changes noticed for $\mathrm{R} 1$ with the addition of a) $\mathrm{Hg}^{2+}$ ions b) $\mathrm{Pb}^{2+}$ ions $\mathrm{c}$ ) $\mathrm{Ni}^{2+}$ ions
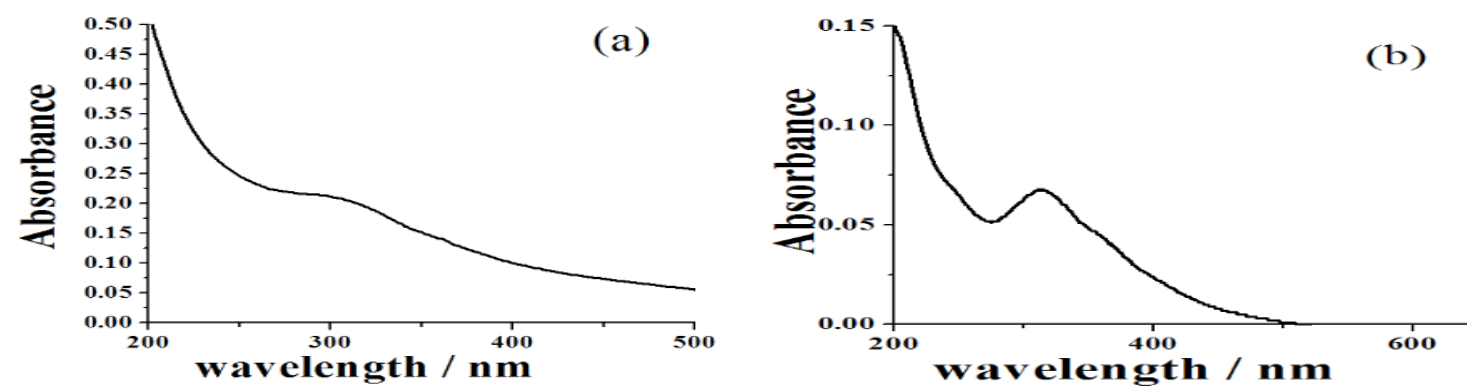

Fig. 6. UV-Visible spectrum of $\mathrm{R} 2$ in a) acetonitrile b) ethanol

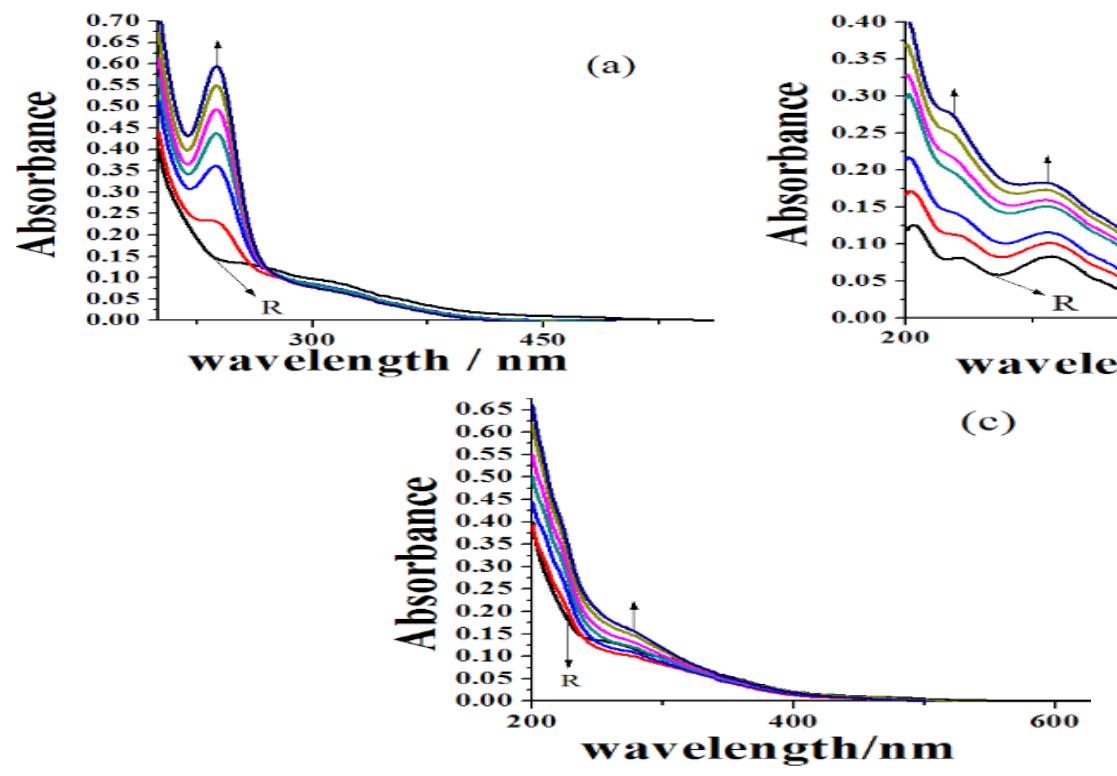

Fig. 7. Change in the absorbance spectrum of $\mathrm{R2}$ with $\mathrm{Cu}^{2+}$ ions a) overall changes b) formation of MLCT band $\mathrm{c}$ ) generation of new peaks at $303 \mathrm{~nm}$ and $354 \mathrm{~nm}$ 

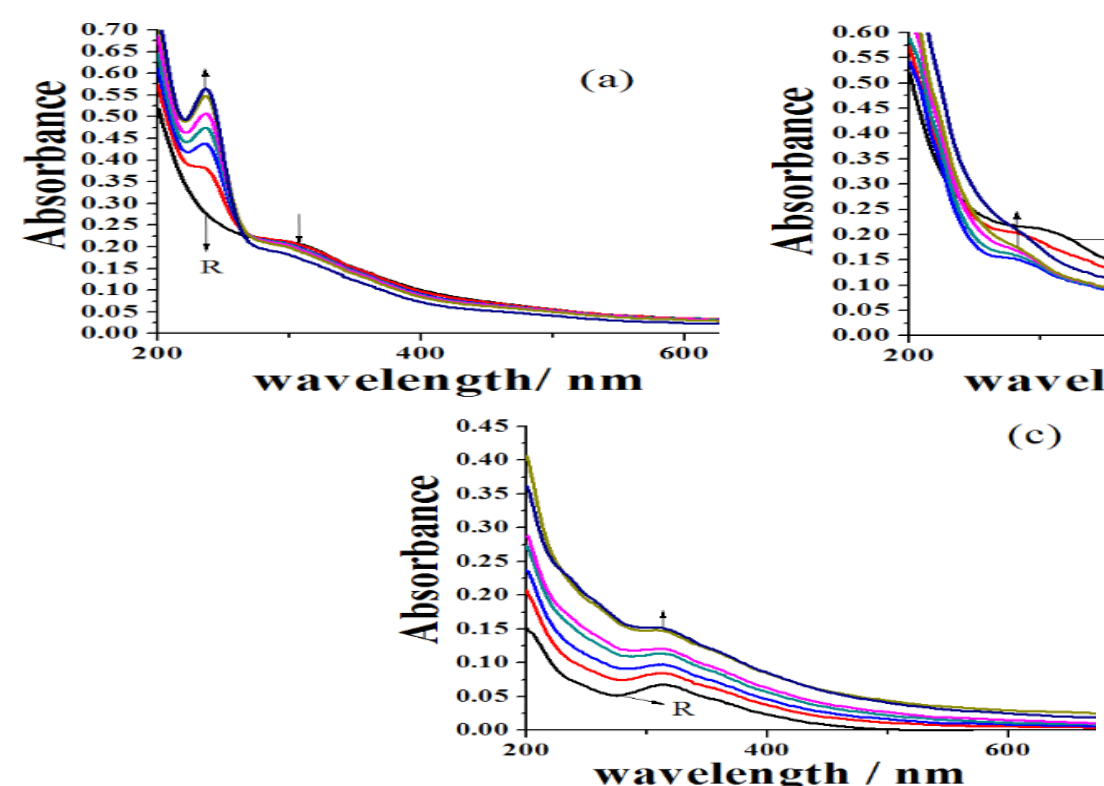

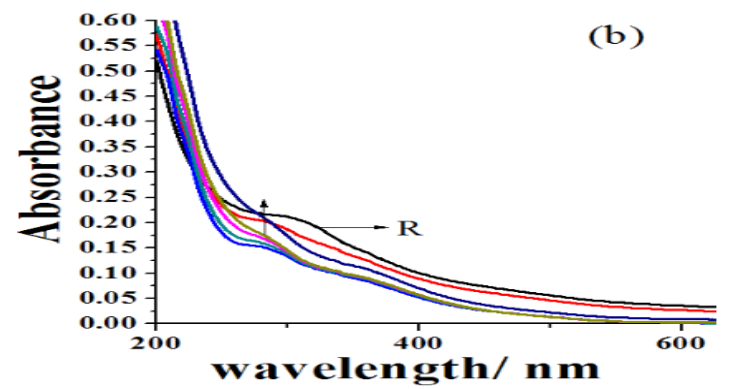

(c)

Fig. 8. Discerning ability of $\mathrm{R2}$ towards a) $\mathrm{Hg}^{2+}$ ions, b) $\mathrm{Ni}^{2+}$ ions, c) $\mathrm{Pb}^{2+}$ ions

Interaction studies with cyclic voltammetry

Responses to the applied potential were documented in cyclic voltammetry to establish the sensing priority order. Increasing $\Delta \mathrm{E}_{\mathrm{p}}, \mathrm{I}_{\mathrm{pa}} \& \mathrm{I}_{\mathrm{pc}}$ values (Table 1) noticed in the voltammograms

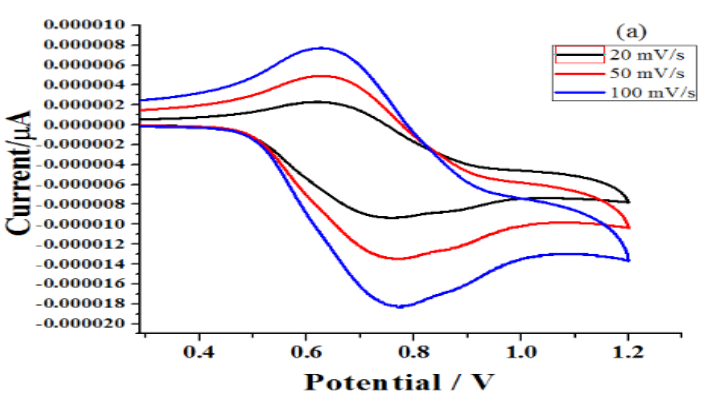

recorded with different scan rate $(20,50$ \& $100 \mathrm{mV} / \mathrm{sec}$ ) for metal free R1 (Fig. 9) and over blowed $\Delta \mathrm{E}_{\mathrm{p}}$ values (99-140 $\mathrm{mV}$ other than the expected $59 \mathrm{mV}$ ) emphasized the quasi-reversible one-electron redox process ${ }^{24}$.

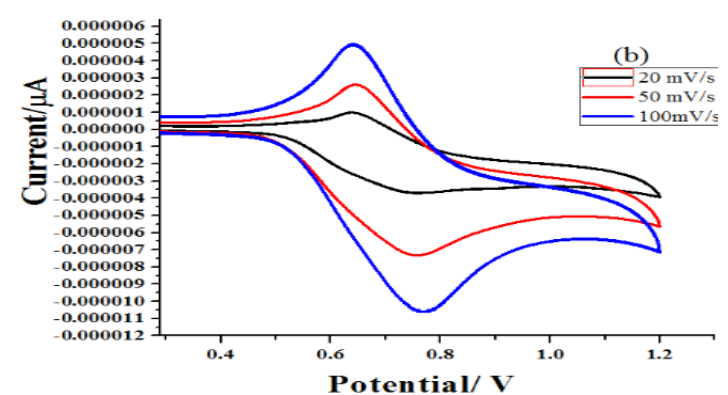

Fig. 9. Cyclic voltammograms of $R 1\left(1 \times 10^{-3} \mathrm{M}\right)$ with different scan rate in a) acetonitrile b) ethanol

Table 1: Electrochemical parameters for R1

\begin{tabular}{ccccccc}
\hline Scan Rate-mV/ sec & $\begin{array}{c}\mathrm{E}_{\mathrm{pa}} \\
(\mathrm{V})\end{array}$ & $\begin{array}{c}\mathrm{E}_{\mathrm{pc}} \\
(\mathrm{V})\end{array}$ & $\begin{array}{c}\Delta \mathrm{E}_{\mathrm{p}} \\
(\mathrm{V})\end{array}$ & $\begin{array}{c}\mathrm{E}_{1 / 2} \\
(\mathrm{~V})\end{array}$ & $\begin{array}{c}\mathrm{I}_{\mathrm{pa}} \times 10^{-5} \\
(\mu \mathrm{A})\end{array}$ & $\begin{array}{c}\mathrm{I}_{\mathrm{pc}} \times 10^{-5} \\
(\mu \mathrm{A})\end{array}$ \\
\hline & & \multicolumn{5}{c}{ Solvent -Acetonitrile } \\
20 & 0.749 & 0.634 & 0.115 & 0.692 & -0.928 & 0.224 \\
50 & 0.76 & 0.632 & 0.128 & 0.696 & -1.346 & 0.495 \\
100 & 0.764 & 0.623 & 0.14 & 0.694 & -1.818 & 0.774 \\
& & Solvent - Ethanol & & 0.371 & 0.09 \\
50 & 0.743 & 0.636 & 0.107 & 0.689 & -0.371 & 0.259 \\
100 & 0.75 & 0.651 & 0.099 & 0.7 & -0.627 & 0.487 \\
\hline
\end{tabular}

The detected positive potential shift for oxidation peak and negative potential shift for reduction peak ${ }^{25-26}$ in the voltammograms logged in the CV titration (to $10 \mathrm{~mL}$ of $10^{-3}$ molar R1 solution 20 $\mu \mathrm{L}$ of $10^{-3}$ molar metal solution were added up to $7 \mathrm{eq}$ ) under equimolar $\left(10^{-3} \mathrm{R} 1 / 10^{-3} \mathrm{M}^{2+}\right)$ and multimolar $\left(10^{-3} \mathrm{R} 1 / 10^{-1} \mathrm{M}^{2+}\right)$ concentration reveals that the synthesized receptors is capable of sensing deferent metal ions. Fig. 10 chronicled for the addition of $\mathrm{Cd}^{2+}$ ions is presented here as a reference. 

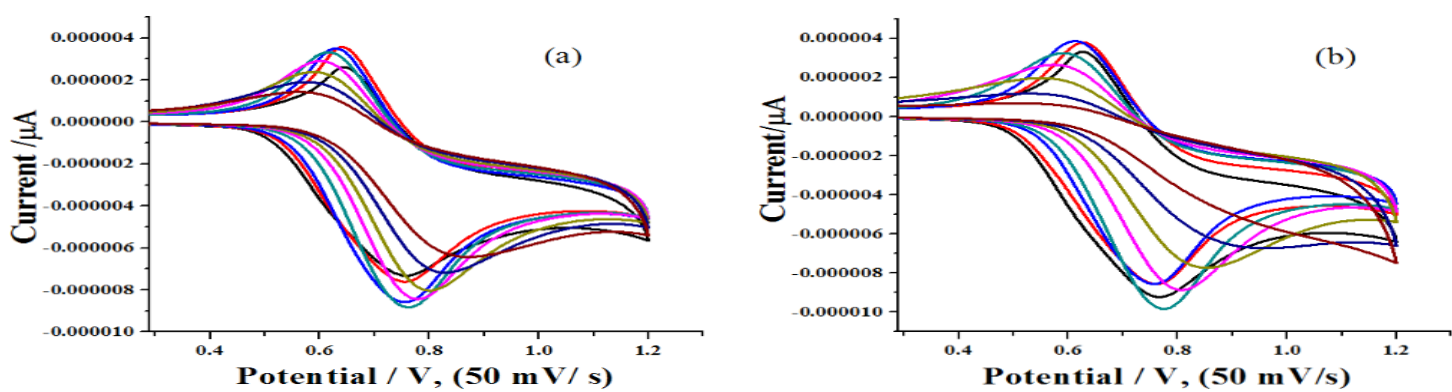

Fig. 10. CV titration study of $\mathrm{R} 1$ and $\mathrm{Cd}^{2+}$ ions $[50 \mathrm{mV} / \mathrm{s}]$ under a) equimolar b) multimolar conditions

The changes noticed in the $\mathrm{I}_{\mathrm{pa}}$ values

(Table 2) for the addition of different metal ions with $10^{-3} \mathrm{M}$ concentration (Fig. 11) and experiential magnified $\Delta \mathrm{E}_{\mathrm{p}}$ amount (111-138 $\mathrm{mV}$ ) discloses the different binding ability of metal cation and also the effect of electrostatic repulsion operated between the oxidized ferrocene moiety and

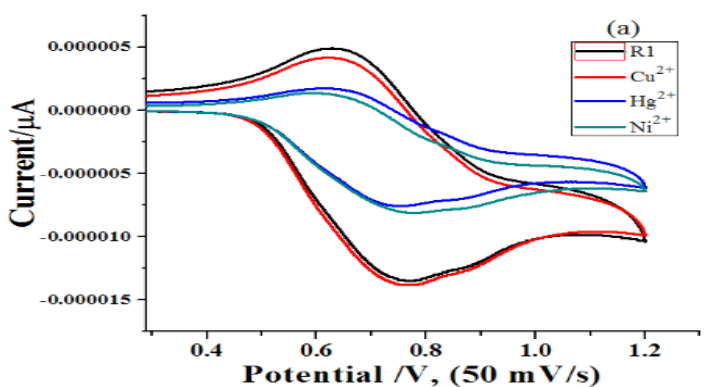

bonded metal cations ${ }^{27}$. Accessing the differences $\left(\Delta \mathrm{I}_{\mathrm{pa}} \%\right)$ between the $\mathrm{I}_{\mathrm{pa}}$ values noticed for the

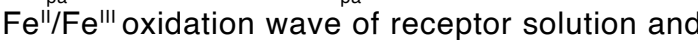
different metal ions added receptor solutions, uncover the coordination order of $\mathrm{R} 1 \mathrm{as}^{\mathrm{Hg}^{2+}}$ $(81)>\mathrm{Pb}^{2+}(17)>\mathrm{Ni}^{2+}(15.7)>\mathrm{Mn}^{2+}(12.8)>\mathrm{Cd}^{2+}(4.2)>$ $\mathrm{Cu}^{2+}(3.7)$.

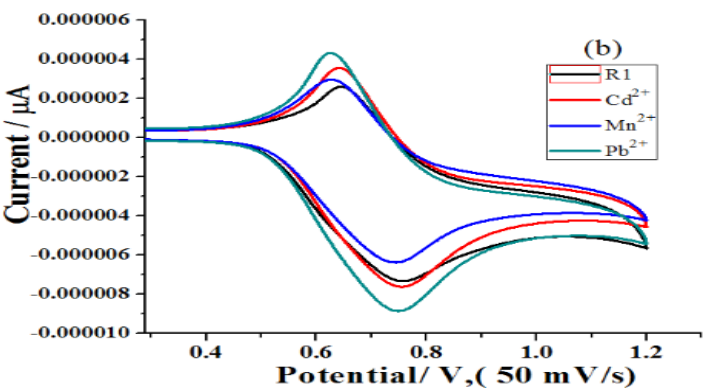

Fig. 11. Cyclic voltammograms recorded for various metal ions with $R 1[50 \mathrm{mV} / \mathrm{s}]$ in a) acetonitrile b) ethanol

Table 2: Electrochemical data for equimolar titration $\left(\mathrm{R} 1,10^{-3} \mathrm{M} / \mathrm{M}^{2+}, 10^{-3} \mathrm{M}\right)(\mathrm{Scan}$ Rate $50 \mathrm{mV} / \mathrm{sec}$ )

\begin{tabular}{|c|c|c|c|c|c|c|}
\hline Addition & $\begin{array}{l}E_{p a} \\
(V)\end{array}$ & $\begin{array}{l}E_{p c} \\
(V)\end{array}$ & $\begin{array}{l}\Delta \mathrm{E}_{\mathrm{p}} \\
(\mathrm{V})\end{array}$ & $\begin{array}{l}E_{1 / 2} \\
(V)\end{array}$ & $\begin{array}{c}I_{p a} \times 10^{-5} \\
(\mu A)\end{array}$ & $\begin{array}{c}I_{p c} \times 10 \\
(\mu \mathrm{A})\end{array}$ \\
\hline \multicolumn{7}{|c|}{ Solvent - Acetonitrile } \\
\hline Receptor & 0.766 & 0.63 & 0.136 & 0.698 & -1.352 & 4.959 \\
\hline $\mathrm{Hg}^{2+}$ & 0.754 & 0.622 & 0.132 & 0.688 & -7.458 & 1.752 \\
\hline $\mathrm{Cu}^{2+}$ & 0.766 & 0.628 & 0.138 & 0.697 & -1.386 & 4.112 \\
\hline $\mathrm{Ni}^{2+}$ & 0.762 & 0.619 & 0.142 & 0.691 & -1.139 & 3.217 \\
\hline \multicolumn{7}{|c|}{ Solvent - Ethanol } \\
\hline Receptor & 0.756 & 0.644 & 0.111 & 0.7 & -7.303 & 2.627 \\
\hline $\mathrm{Cd}^{2+}$ & 0.754 & 0.64 & 0.113 & 0.697 & -7.624 & 3.591 \\
\hline $\mathrm{Mn}^{2+}$ & 0.745 & 0.624 & 0.121 & 0.685 & -6.361 & 2.985 \\
\hline $\mathrm{Pb}^{2+}$ & 0.748 & 0.624 & 0.124 & 0.686 & -8.869 & 4.353 \\
\hline
\end{tabular}

For multimolar concentration, witnessed (Table 3) binding power based on declining in $\Delta \mathrm{l}_{\mathrm{pa}}$ (\%) of oxidation tendency of metal ion coupled with $\mathrm{R} 1$ is $\mathrm{Cu}^{2+}(86.07)>\mathrm{Hg}^{2+}(85.6)>\mathrm{Ni}^{2+}(85.47)>$ $\mathrm{Cd}^{2+}(15.4)>\mathrm{Mn}^{2+}(81.96)>\mathrm{Pb}^{2+}(83.15)$. Comparison of sensing priority of R1 towards several metal ions at homo and hetero molecular concentrations divulge $\mathrm{R} 1$ is effective towards $\mathrm{Cu}, \mathrm{Hg}$, and $\mathrm{Ni}$ ions at higher concentration of metal salts and at lower concentration adept lead for $\mathrm{Hg}, \mathrm{Pb}$ and $\mathrm{Ni}$ ions (Figure 12).

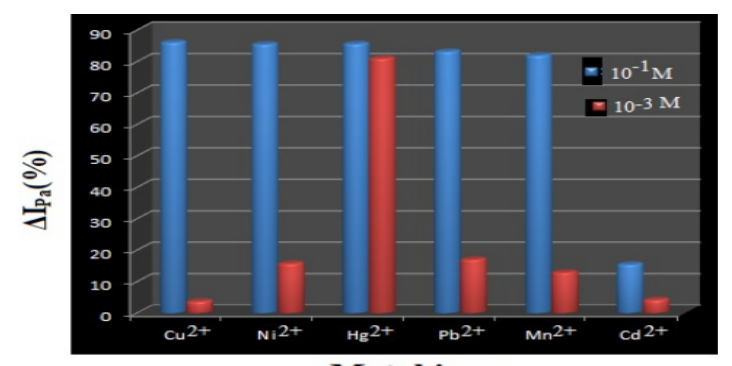

Metal ions

Fig. 12. Comparison of sensing ability of R1and metal ion concentration 
Table 3: Electrochemical data for multimolar titration $\left(\mathrm{R} 1,10^{-3} \mathrm{M} / \mathrm{M}^{2+}, 10^{-1} \mathrm{M}\right)$ ) (Scan Rate-50 $\left.\mathrm{mV} / \mathrm{sec}\right)$

\begin{tabular}{|c|c|c|c|c|c|c|}
\hline Addition & $\begin{array}{l}E_{p a} \\
(V)\end{array}$ & $\begin{array}{l}E_{p c} \\
(V)\end{array}$ & $\begin{array}{l}\Delta \mathrm{E}_{\mathrm{p}} \\
(\mathrm{V})\end{array}$ & $\begin{array}{l}E_{1 / 2} \\
(V)\end{array}$ & $\begin{array}{c}I_{p a} \times 10^{-6} \\
(\mu A)\end{array}$ & $\begin{array}{c}I_{p c} \times 10^{-6} \\
(\mu A)\end{array}$ \\
\hline \multicolumn{7}{|c|}{ Solvent - Acetonitrile } \\
\hline Receptor & 0.766 & 0.63 & 0.136 & 0.698 & -1.352 & 4.959 \\
\hline $\mathrm{Hg}^{2+}$ & 0.791 & 0.638 & 0.152 & 0.714 & -9.39 & 3.592 \\
\hline $\mathrm{Cu}^{2+}$ & 0.801 & 0.642 & 0.159 & 0.722 & -9.709 & 2.47 \\
\hline $\mathrm{Ni}^{2+}$ & 0.774 & 0.651 & 0.123 & 0.712 & -9.31 & 2.231 \\
\hline \multicolumn{7}{|c|}{ Solvent - Ethanol } \\
\hline Receptor & 0.756 & 0.644 & 0.111 & 0.7 & -7.303 & 2.627 \\
\hline $\mathrm{Cd}^{2+}$ & 0.764 & 0.628 & 0.136 & 0.696 & -8.63 & 3.869 \\
\hline $\mathrm{Mn}^{2+}$ & 0.793 & 0.603 & 0.19 & 0.698 & -1.317 & 6.233 \\
\hline $\mathrm{Pb}^{2+}$ & 0.781 & 0.607 & 0.173 & 0.694 & -1.23 & 4.393 \\
\hline
\end{tabular}

Like R1, R2 also display same trend (Table 4) in the values of $\Delta \mathrm{E}_{\mathrm{p}}, \mathrm{I}_{\mathrm{pa}}$ and $\mathrm{I}_{\mathrm{pc}}$ upon scanning with different scan rate.

Homo molar $\left(10^{-3}, \mathrm{R} 2 / 10^{-3}, \mathrm{M}^{2+}\right)$ and hetero molar $\left(10^{-3}, \mathrm{R} 2 / 10^{-1}, \mathrm{M}^{2+}\right)$ titration studies (Fig.13) exemplify similar sensing behavior to metal ions. Calculated $\Delta \mathrm{I}_{\mathrm{pa}}(\%)$ values depict, fastening trend for R2 under same molar condition as $\mathrm{Pb}^{2+}(81.3)>\mathrm{Cu}^{2+}(76.8)>\mathrm{Mn}^{2+}(73.35)>\mathrm{Ni}^{2+}(23.6)>$ $\mathrm{Cd}^{2+}(22.12)>\mathrm{Hg}^{2+}(8.4)$ (Table 5) and for different molar it is $\mathrm{Cd}^{2+}(82.1)>\mathrm{Mn}^{2+}(80.4)>\mathrm{Pb}^{2+}(79)>\mathrm{Cu}$ ${ }^{2+}(26.1)>\mathrm{Ni}^{2+}(22.3)>\mathrm{Hg}^{2+}(18.1)$ (Table 6). Above observation relate that $\mathrm{R} 2$ shows better recognition

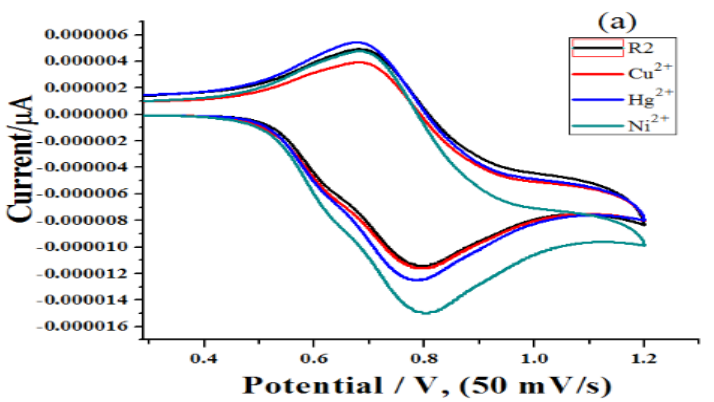

to $\mathrm{Pb}, \mathrm{Cu}$ and $\mathrm{Mn}$ ions at lower concentration. Higher quantity of $\mathrm{Cd}^{2+}$ is requisite for finding (Figure 14).

\section{Antimicrobial Studies}

Disc diffusion method (Mueller Hinton Agar base) was adopted to discover antibacterial activity of R1 \& R2 against Streptococcus faecalise, Staphylococcuse aureuse, Salmonella typhimurium and Escherichia coli (Fig.15). Likewise, anti-fungal studies for fungi Candida albicans and Aspergillus nigerwas done using Sabouraud's Dextrose agar as base (Fig.16). Table 7 highlights the zone of inhibition in $\mathrm{mm}$ perceived for the synthesized compounds $\mathrm{R} 1$ \& $R 2$ in antimicrobial analysis.

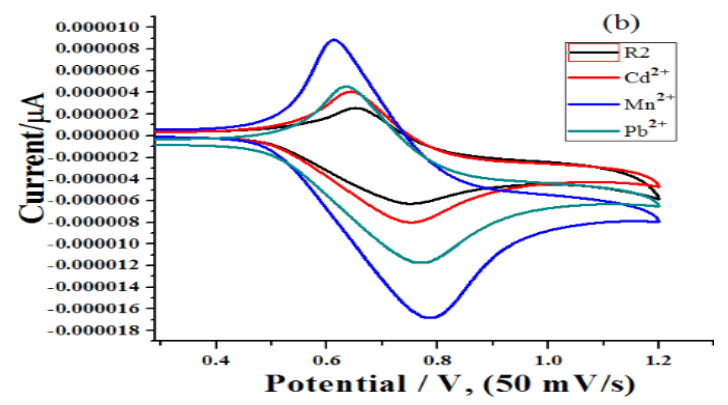

Fig. 13. Changes in $C V$ of $R 2$ upon addition of different metal ion [50 mV/s] a) acetonitrile b) ethanol

Table 4: Electrochemical parameters for $\mathrm{R2}$

\begin{tabular}{|c|c|c|c|c|c|c|}
\hline Scan Rate-mV/sec & $\begin{array}{l}E_{p a} \\
(V)\end{array}$ & $\begin{array}{l}E_{p c} \\
(V)\end{array}$ & $\begin{array}{l}\Delta \mathrm{E}_{\mathrm{p}} \\
(\mathrm{V})\end{array}$ & $\begin{array}{l}E_{1 / 2} \\
(V)\end{array}$ & $\begin{array}{c}\text { Ipax10-5 } \\
(\mu \mathrm{A})\end{array}$ & $\begin{array}{c}\mathrm{I}_{p c} \times 10^{-6} \\
(\mu \mathrm{A})\end{array}$ \\
\hline \multicolumn{7}{|c|}{ Solvent -Acetonitrile } \\
\hline 20 & 0.787 & 0.683 & 0.103 & 0.735 & -0.746 & 2.822 \\
\hline 50 & 0.795 & 0.685 & 0.109 & 0.74 & -1.137 & 4.846 \\
\hline \multicolumn{7}{|c|}{ Solvent - Ethanol } \\
\hline 20 & 0.741 & 0.648 & 0.092 & 0.695 & -0.397 & 0.681 \\
\hline 50 & 0.75 & 0.651 & 0.099 & 0.7 & -0.638 & 2.531 \\
\hline 100 & 0.766 & 0.642 & 0.124 & 0.704 & -1.037 & 5.328 \\
\hline
\end{tabular}


Table 5: CV data for homo molar titration $\left(\mathrm{R} 2,10^{-3} \mathrm{M} / \mathrm{M}^{2+}, 10^{-3} \mathrm{M}\right)$ (Scan Rate-50 mV/ sec)

\begin{tabular}{|c|c|c|c|c|c|c|}
\hline Addition & $\begin{array}{l}E_{p a} \\
(V)\end{array}$ & $\begin{array}{l}E_{p c} \\
(V)\end{array}$ & $\begin{array}{l}\Delta \mathrm{E}_{\mathrm{p}} \\
(\mathrm{V})\end{array}$ & $\begin{array}{l}E_{1 / 2} \\
(V)\end{array}$ & $\begin{array}{c}\text { Ipa } \times 10^{-5} \\
(\mu \mathrm{A})\end{array}$ & $\begin{array}{c}\text { Ipc } \times 10^{-6} \\
(\mu \mathrm{A})\end{array}$ \\
\hline \multicolumn{7}{|c|}{ Acetonitrile- solvent } \\
\hline Receptor & 0.799 & 0.685 & 0.113 & 0.742 & -1.143 & 4.888 \\
\hline $\mathrm{Hg}^{2+}$ & 0.785 & 0.675 & 0.109 & 0.73 & -1.248 & 5.426 \\
\hline $\mathrm{Cu}^{2+}$ & 0.799 & 0.685 & 0.113 & 0.742 & -1.152 & 3.961 \\
\hline $\mathrm{Ni}^{2+}$ & 0.803 & 0.681 & 0.121 & 0.742 & -1.498 & 4.849 \\
\hline \multicolumn{7}{|c|}{ Ethanol - solvent } \\
\hline Receptor & 0.75 & 0.651 & 0.099 & 0.7 & -6.277 & 2.593 \\
\hline $\mathrm{Cd}^{2+}$ & 0.752 & 0.642 & 0.109 & 0.697 & -8.057 & 4.05 \\
\hline $\mathrm{Mn}^{2+}$ & 0.781 & 0.613 & 0.167 & 0.697 & -1.672 & 8.89 \\
\hline $\mathrm{Pb}^{2+}$ & 0.774 & 0.634 & 0.14 & 0.704 & -1.172 & 4.565 \\
\hline
\end{tabular}

Table 6: CV data for hetero molar titration $\left(\mathrm{R2}, 10^{-3} \mathrm{M} / \mathrm{M}^{2+}, 10^{-1} \mathrm{M}\right)($ Scan Rate-50 $\mathrm{mV} / \mathrm{sec})$

\begin{tabular}{|c|c|c|}
\hline Addition & $\begin{array}{l}E_{p a} \\
\text { (V) }\end{array}$ & $\begin{array}{l}E_{p c} \\
(V)\end{array}$ \\
\hline Receptor & 0.799 & 0.685 \\
\hline $\mathrm{Hg}^{2+}$ & 0.795 & 0.659 \\
\hline $\mathrm{Cu}^{2+}$ & 0.797 & 0.661 \\
\hline $\mathrm{Ni}^{2+}$ & 0.777 & 0.659 \\
\hline Receptor & 0.75 & 0.651 \\
\hline $\mathrm{Cd}^{2+}$ & 0.777 & 0.6221 \\
\hline $\mathrm{Mn}^{2+}$ & 0.756 & 0.624 \\
\hline $\mathrm{Pb}^{2+}$ & 0.768 & 0.619 \\
\hline
\end{tabular}

Fig. 14. Comparison of binding ability of R2 and metal ion concentration
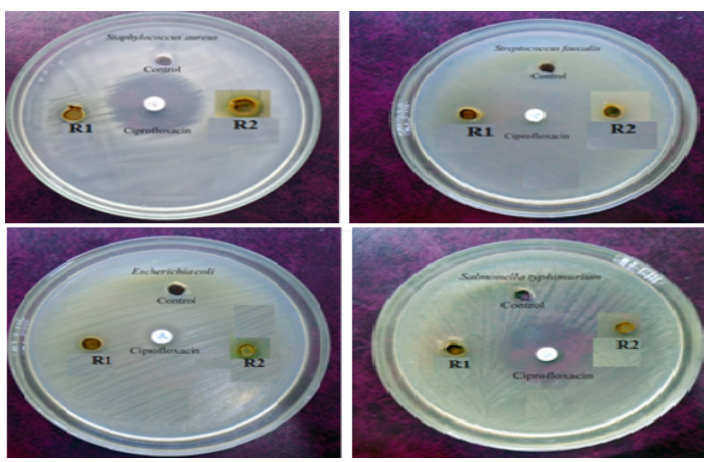

Fig. 15. Zone of inhibition for a) Streptococcus faecalise, b) Staphylococcuse aureuse, c) Salmonella typhimurium and d) Escherichia colt

$\begin{array}{llcc}\Delta \mathrm{E}_{\mathrm{p}} & \mathrm{E}_{1 / 2} & \mathrm{I}_{\mathrm{pa}} \times 10^{-5} & \mathrm{I}_{\mathrm{pc}} \times 10^{-6} \\ (\mathrm{~V}) & (\mathrm{V}) & (\mu \mathrm{A}) & (\mu \mathrm{A})\end{array}$

Solvent -Acetonitrile

\begin{tabular}{lccc}
0.113 & 0.742 & -1.143 & 4.888 \\
0.136 & 0.727 & -1.397 & 5.451 \\
0.136 & 0.729 & -1.548 & 5.785 \\
0.117 & 0.718 & -1.473 & 5.653 \\
$\begin{array}{l}\text { ent -Ethanol } \\
0.099\end{array}$ & 0.7 & -6.277 & \\
0.154 & 0.699 & -1.117 & 5.593 \\
0.132 & 0.69 & -1.226 & 5.649 \\
0.148 & 0.694 & -1.306 & 7.112 \\
\hline
\end{tabular}
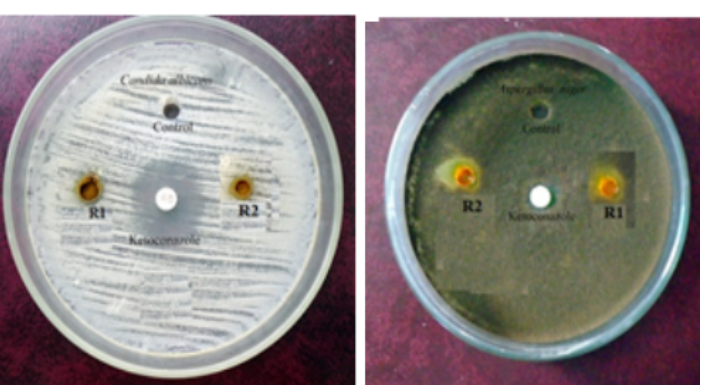

Fig. 16. Zone of inhibition for a) Candida albicans b) Aspergillus niger

Defense mechanism rendered by $\mathrm{R} 1$ and $\mathrm{R} 2$ to prevent the growth of fungus Aspergillus niger is nearly 150 to $160 \%$ higher than that of the value witnessed for the standard Ketoconazole, which is unusual. Fungus Candida albicans progress is also prevented up to $50 \%$ of the standard value. Above result discloses that the compound $\mathrm{R} 1$ can be examined for antifungal agents formulation as there are only minimum numbers of antifungal agents available in the market ${ }^{15}$. Retardant nature of R1 \& R2 displayed for two Gram-positive and two Gram-negative bacteria are on par with standard Ciprofloxacin. 
Table7: In-vitro antimicrobial studies data

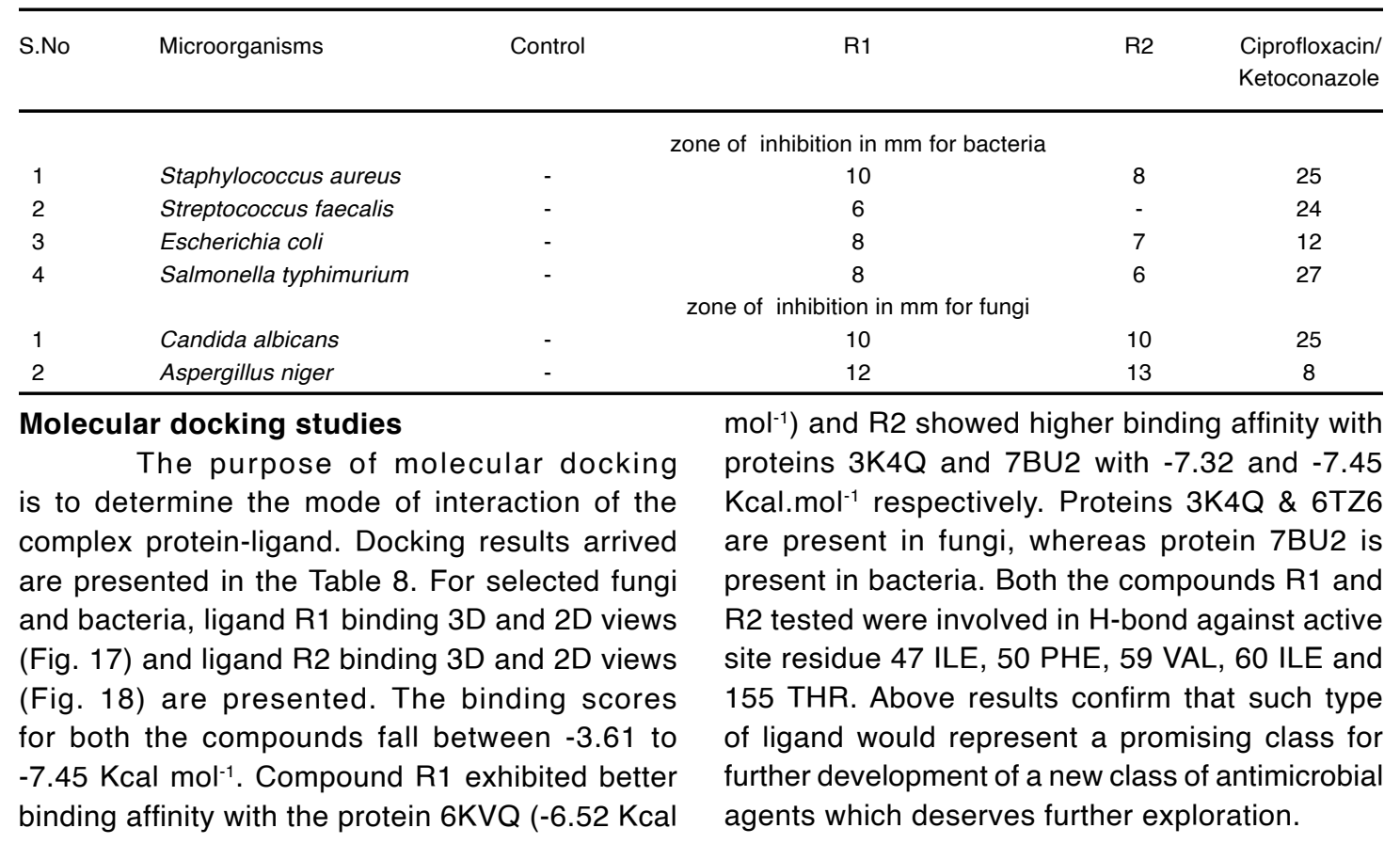

Table 8: Results obtained from molecular docking studies

\begin{tabular}{|c|c|c|c|c|c|c|}
\hline \multirow[t]{2}{*}{ PDB } & \multicolumn{2}{|c|}{ Free binding energy, $\mathrm{kcal} \mathrm{mol}^{-1}$} & \multirow{2}{*}{$\begin{array}{l}\text { R1 } \\
\text { Hydrogen bonds with } \\
\text { receptor amino acids }\end{array}$} & \multicolumn{3}{|c|}{$\mathrm{R} 2$} \\
\hline & $\mathrm{R} 1$ & $\mathrm{R} 2$ & & Distance $(\AA ̊)$ & $\begin{array}{l}\text { Hydrogen bonds with } \\
\text { receptor amino acids }\end{array}$ & Distance $(\AA)$ \\
\hline & & & 30-TYR & 3.93 & 23-VAL & 3.44 \\
\hline \multirow[t]{5}{*}{ 1PTF } & -3.61 & -4.69 & 50-PHE & 3.69 & 24-GLN & 3.95 \\
\hline & & & 59-VAL & 3.88 & 28-LYS & 3.80 \\
\hline & & & 60-ILE & 3.98 & 47-ILE & 3.66 \\
\hline & & & 114-PHE & 3.23 & & \\
\hline & & & 45-LYS & 3.04 & 27-GLN & 3.91 \\
\hline \multirow[t]{3}{*}{$3 K 4 Q$} & -4.18 & -7.32 & 47-ILE & 2.15 & 277-LYS & 3.55 \\
\hline & & & & & 278-LYS & 3.37 \\
\hline & & & 22-VAL & 3.90 & 26-ALA & 3.67 \\
\hline \multirow[t]{5}{*}{$4 Y X B$} & -5.21 & -6.54 & 155-THR & 3.19 & 28-ILE & 3.83 \\
\hline & & & 157-GLU & 3.56 & 29-PRO & 3.78 \\
\hline & & & 190-LEU & 3.70 & 46-ILE & 3.27 \\
\hline & & & 225-LEU & 3.30 & 51-ARG & 3.23 \\
\hline & & & 153-LYS & 2.27 & 188-ASN & 3.32 \\
\hline \multirow[t]{4}{*}{$6 \mathrm{KVQ}$} & -6.52 & -5.26 & 155-THR & 3.05 & 189-VAL & 3.50 \\
\hline & & & $192-A S N$ & 3.27 & & \\
\hline & & & 198-GLY & 3.76 & & \\
\hline & & & 103-ASP & 2.95 & 50-PHE & 3.84 \\
\hline \multirow[t]{4}{*}{ 6TZ6 } & -5.23 & -6.3 & 142-ARG & 2.73 & 59-VAL & 3.74 \\
\hline & & & 142-ARG & 2.79 & 60-ILE & 3.65 \\
\hline & & & & & 97-TYR & 3.72 \\
\hline & & & 50-PHE & 3.84 & 42-HIS & 3.64 \\
\hline \multirow[t]{3}{*}{ 7BU2 } & -5.48 & -7.45 & 59-VAL & 3.74 & 180-LEU & 3.85 \\
\hline & & & 60-ILE & 3.65 & 240-ASN & 3.31 \\
\hline & & & & & 332-ARG & 3.75 \\
\hline
\end{tabular}



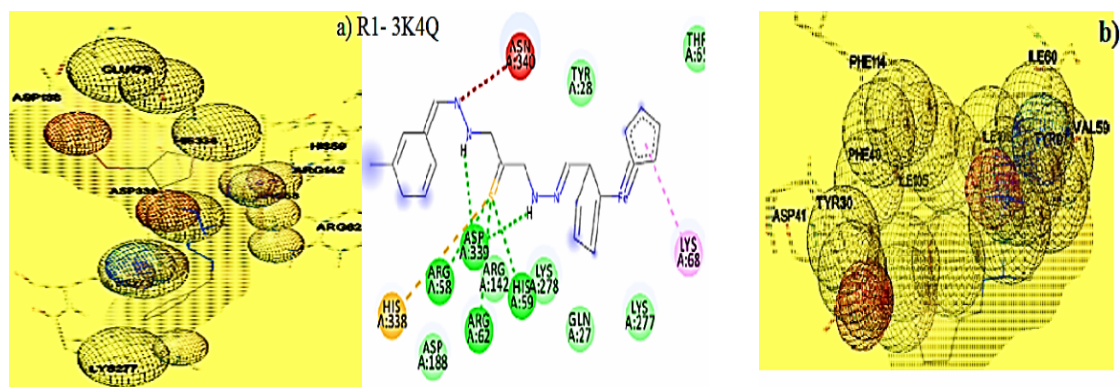

b) R1- 6TZ6
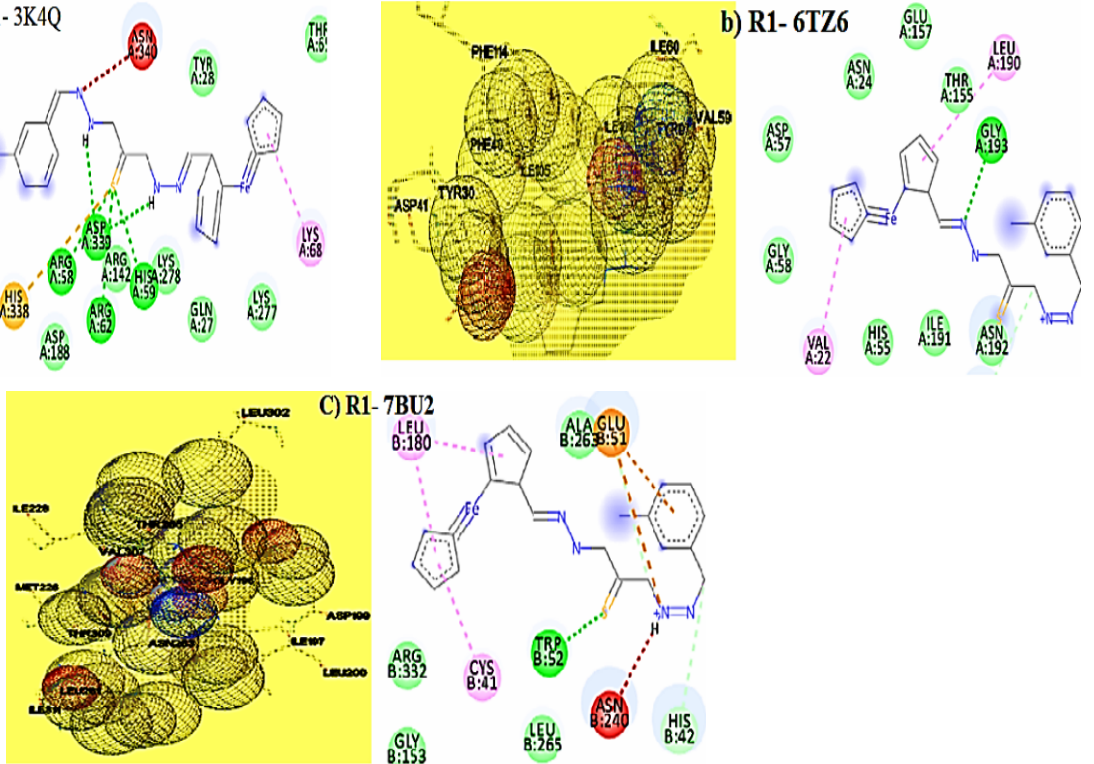

Fig. 17. Docked pose view of R1 with a) $3 K 4 Q$ b) $6 T Z 6$ c) 7BU2
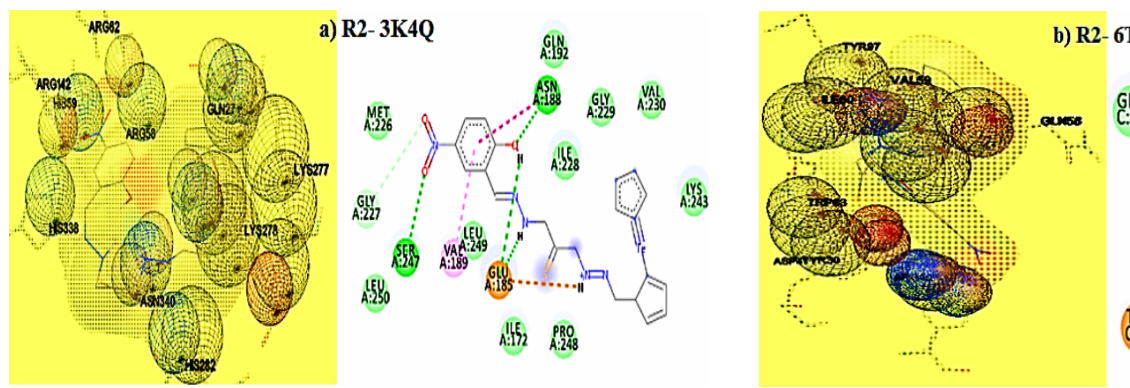

b) R2-6TZ6
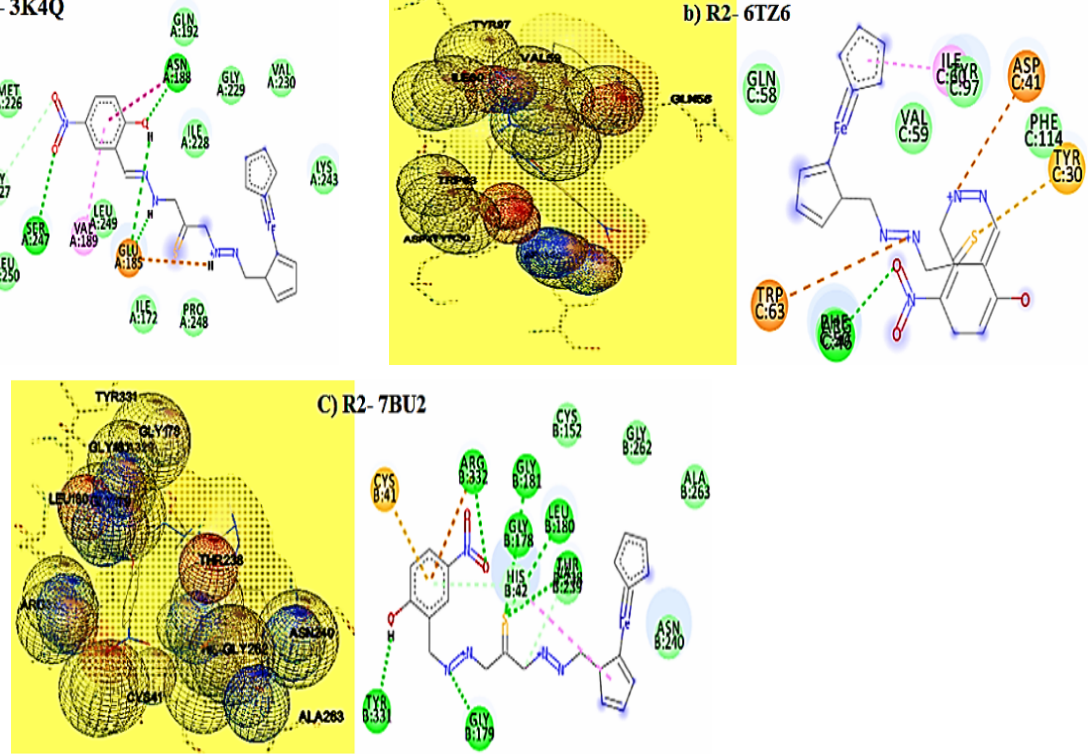

C) R2-7BU2

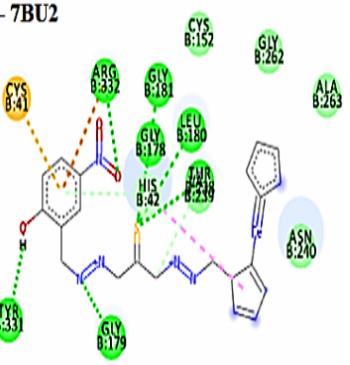

Fig.18. Docked pose view of R2 with a) $3 K 4 Q$ b) $6 T Z 6$ c) 7BU2

\section{CONCLUSION}

Synthesis of unsymmetrical Schiff base compounds having ferrocencarboxaldehyde azomethine at one end and imine with aromatic aldehyde at the other end has not been reported so far. Our team have overawed the hurdles faced by the scientist by synthesizing Schiff bases $N^{\prime}-((E)-2$-nitrobenzylidene)-2-((E)-2(ferrocenylidene)hydrazine-1-carbothiohydrazide and $N^{\prime}-((E)-2$-hydroxy-5-nitrobenzylidene-2-((E)-2- (ferrocenylidene)hydrazine-1-carbothiohydrazide. Spectral analysis by FTIR, ${ }^{1} \mathrm{HNMR}$ and Mass spectrum authenticate the formation of desired sensors. Multi-metal ions sensing competency of newly prepared materials have been uncovered in UV-Visible spectral studies. Results elucidated from electrochemical studies are harmonized with the data of electronic spectral studies. Assessment of difference in anodic current perceived $\left(\Delta \mathrm{l}_{\mathrm{pa}}\right)$ throwback the relation between the concentration of metal ions and receptors for appropriate binding. 
Exaggerated antifungal activities identified in in-vitro studies and high free binding energy values observed in molecular docking studies for fungus Aspergillus niger, provoke the rhythm of pharmaceutical research to be under taken.

\section{ACKNOWLEDGEMENT}

The authors acknowledge the support from
Dr. K. Pandian, Professor of Inorganic Chemistry \& Controller of Examinations, University of Madras for the UV-Visible spectral studies free of cost. The research scholar D. Saranya wishes to record her thanks to the State Government of Tamil Nadu, India for the annual research assistant grant.

\section{Conflicts of interest}

"There are no conflicts to declare".

\section{REFERENCES}

1. Lu, Y.; Liang, X.; Niyungeko, C.; Zhou, J.; Xu, J.; Tian, G. Talanta., 2018, 178, 324-338.http:// dx.doi.org/10.1016/j.talanta.2017.08.033.

2. a) Bansod, B.; Kumar, T.; Thakur, R.; Rana, S.; Singh, I. Biosensors \& Bioelectronics., 2017, 94, 443-455 http://dx.doi.org/10.1016/j. bios.2017.03.031. b) Wright, A. T.; Anslyn, E. V. Anslyn. Chem. Soc. Rev., 2006, 35, 14-28. http://dx.doi.org/10.1039/B505518K. c) Lee, J. H.; Wang, Z.; Liu, J.; Lu, Y. J. Am. Chem. Soc., 2008, 130, 14217-14226. http://dx.doi. org/10.1021/ja803607z.

3. a) Xu, L.-W.; Wang, X.-T.; Zou, Y.-H.; Yu, X.-Y.; Xie, C.-Z.; Qiao, X.; Xu, J.-Y. Appl Orgamet Chem., 2020, e5812, 1-15. https://doi. org/10.1002/aoc.5812.b) Shaya, A-R.; İpek O.; Doğan ,E.;Mahmut, D. Turkish Journal of Chemistry., 2020, 44, 1254-1264. https://doi. org/10.3906/kim-2004-68.

4. a) Andrea, B.; Vito, L. Coordination Chemistry Revie., 2012, 256, 149-169 http://dx.doi. org/10.1016/j.ccr.2011.05.015. b) Smith, D. G.; Topolnicki, I. L.; Zwicker, V. E.; Jolliffe, K. A.; New, E. J. New. Royal Society of Chemistry., 2017, 142(19), 3544-3563. http:// dx.doi.org/10.1039/c7an01200d.

5. Lee, J. J.; Choi, Y. W.; You, G. R.; Lee, S. Y.; Kim, C. Dalton Trans., 2015, 44,1330513314. http://dx.doi.org/10.1039/c5dt00957j.

6. a ) Mondal, A.; Roy Chowdhury, A.; Bhuyan, S.; Mukhopadhyay, S. K.; Banerjee, P. Dalton Trans., 2019, c8dt05097j ,1-12. http://dx.doi. org/10.1039/c8dt05097j. b)Qi, X.; Jun, E. J.; Xu, L.; Kim, S.-J.; Joong Hong, J. S.; Yoon, Y. J.; Yoon, J. J. Org. Chem., 2006, 71, 28812884. http://dx.doi.org/10.1021/jo052542a.

7. a) Ahmad Wani, M.; Thakur, N.; Pandey, M. D.; Pandey, R. New Journal of Chemistry., 2017, 41(18), 10000-10008. http://dx.doi. org/10.1039/C7NJ02097J. b) Gaetke, L.; Ching Kuang., Toxicology., 2003, 189, 147-163. http://
dx.doi.org/10.1016/S0300-483X(03)00159-8.

8. a) Vinita, B.; Valeria M, Nurchi.; Suban, K.; Sahoo., Pharmaceuticals., 2021, 14, 123(145). https://doi.org/10.3390/ph14020123 b) Zapata, F.; Caballero, A.; Molina, P.; Tarraga, A. Tarraga. Senso., 2010, 10, 11311-11321. http://dx.doi.org/10.3390/s101211311.

9. Goswami, S.; Chakraborty, S.; Paul, S.; Halder, S.;Maity, A. C., Tetrahedron Lett., 2013, 54, 5075-5077. https://doi.org/10.1016/ j.tetlet.2013.07.051.

10. Ellez-P; Navas-Acien,M.; Crainiceanu,A.; C,M.; Guallar, E., Environ. Health Perspect., 2008, 116, 51-56. https://doi.org/10.1289/ehp.10764.

11. Sunnapu, O.; Kotla, N. G.; Maddiboyina, B.;Singaravadivel, S.; Sivaraman, G. $R S C$ $A d v .$, 2016, 6, 656-660. https://dx.doi. org/10.1039/c5ra20482h.

12. Aschner, M.; Guilarte, T. R.; Schneider, J. S.; Zheng, W. Toxicology and Applied Pharmacology., 2007, 221(2), 131-147. https://doi.org/10.1016/j.taap.2007.03.001.

13. Ragavi, V.; Reshma, J.; Ananthi, M. Organic \& Medicinal Chem I J., 2018, 5(3), 1-6. https:// dx.doi.org/10.19080/OMClJ. 2018.05.555662.

14. Sinha, D.; Tiwari, A. K.; Singh, S.; Shukla, G.; Mishra, P.; Chandra, H.; Mishra, A. K. Journal of Medicinal Chemistry., 2008, 43, 160-165. https://doi.org/10.1016/j.ejmech.2007.03.022

15. a) Buda De Cesare, G.; Cristy, S. A.; Garsin, D. A.; Lorenz, M. C. mBio., 2020, 11(6), e02123-20. https://dx.doi:10.1128/ mbio.02123-20 b) Azevedo, M. M.; TeixeiraSantos, R.; Silva, A. P.; Cruz, L.; Ricardo, E.; Pina-Vaz, C.; Rodrigues, A. G. Microbiology., 2015, 6, 669(1-7). https://dx.doi.org/10.3389/ fmicb.2015.00669.

16. Mohamed, A. M.; Mohamed, E. K.; Koketsu, M. American Journal of Chemistry., 2012, 2(2), 38-51. https://dx.doi.org/10.5923/j. chemistry.20120202.09. 
17. Bagamboula, C.F.; Uyttendaele, M.; Debevere, J. Food Microbiology., 2004, 21, 33-42. https:// dx.doi.org/10.1016/s0740-0020(03)00046-7.

18. Morris, G.M.; Huey, R.; Lindstrom, W.; Sanner, M. F.; Belew, R. K.; Goodsell, D.S.; Olson, A.J. J. of Computational Chem., 2009, 30, 27852791. https://dx.doi.org/10.1002/jcc.21256.

19. Constantinescu, C.; Matei, A.; Ion, V.; Mitu, B.; Ionita, I.; Dinescu, M.; Emandi, A. Applied Surface Science., 2014, 302, 83-86. http:// dx.doi.org/10.1016/j.apsusc.2013.11.147.

20. a) Gryaznova, T. P.; Katsyuba, S. A.; Milyukov, V. A.; Sinyashin, O. G. (2010). J. of Organomet. Chem., 2010, 695, 2586-2595. https://dx.doi. org/10.1016/j.jorganchem.2010.08.031 b) Sarhan, A. A. O.; Ibrahim, M. S.; Kamal, M. M.; Mitobe, K.; Izumi, T. Monatshefte Für ChemieChemical Monthly., 2008, 140, 315-323 https:// dx.doi.org/10.1007/s00706-008-0025-2.

21. Abi, M.; Subroto, C.; Suwamo. Energies., 2018, 11,364(1-12).https://doi.org/10.3390/en11020364.
22. Pandey, R.; Gupta, R. K.;Shahid, M.; Maiti, B.; Misra, A.; Pandey, D. S. Inorg. Chem., 2012, 51, 298-311. https://dx.doi.org/10.1021/ic201663m.

23. Benramdane, R.; Benghanem, F.; Ourari, A.; Keraghel, S.; Bouet, G. J. Coord. Chem., 2015, 68, 560-572. https://dx.doi.org/10.108 0/00958972.2014.994514.

24. Kamatchi, P.; Selvaraj S.; Kandaswamy, M. Polyhendron., 2005, 24, 900-908. https:// dx.doi:10.1016/j.poly.2005.02.012.

25. Li, M.; Wang, R.; Earth Environ. Sci., 2017, 61, 012043(1-5). https://dx.doi.org/ 10.1088/1755-1315/61/1/012043.

26. Alfonso, M.; Tárraga, A.; Molina, P. Dalton Trans., 2010, 39, 8637-8645. https://dx.doi. org/10.1039/c0dt00450b

27. Kamal, A., Kumar, S.; Kumar, V.; Mahajan, R. K. Sensors and Actuators B: Chemical., 2015, 22, 370-378. https://dx.doi.org/10.1016/j. snb.2015.06.147. 